\title{
Model Pembelajaran Tematik Integratif Berbasis Sosiokultural Pendidikan Anak Usia Dini di Kabupaten Melawi
}

\author{
${ }^{1}$ WARIDAH, ${ }^{2}$ KARTINI \\ 1,2 Program Studi Pendidikan Guru Pendidikan Anak Usia Dini, STKIP Melawi, Indonesia. \\ Email: ${ }^{1}$ ida_waridah@yahoo.com, ${ }^{2}$ kartini11@gmail.com
}

DOI: https://doi.org/10.29313/ga.v1i2.3311

\begin{abstract}
The problem of this research is that teachers are not ready to run the government's demands in implementing Curriculum 2013 and the unavailability of thematic-integrative learning tools in the form of RPPM, RPPH, learning media and sociocultural based learning test result. This research produces a sociocultural-based thematic-integrative learning model that is appropriate for learners and knows the effectiveness of sociocultural-based thematic-integrative learning tools. This type of research is research and development. Development is done by referring to Borg and Gall development model that is exploration, planning, product development, product test, and finalization. The subjects of the research trial are all PAUD students in Melawi district. The results of this study indicate that the results of the validation of experts, practitioners, and colleagues indicate socioculturalbased thematic-integrative learning tools deserve to be used with the very good category. Effectiveness in terms of observations and questionnaires get the very good category and very positive response.
\end{abstract}

Keywords: thematic integrative, learning equipment, and socio-cultural.

\begin{abstract}
Abstrak
Permasalahan penelitian ini yaitu guru belum siap menjalankan tuntutan pemerintah dalam melaksanakan Kurikulum 2013 dan belum tersedianya perangkat pembelajaran tematikintegratif berupa RPPM, RPPH, media pembelajaran dan tes hasil belajar yang berbasis sosiokultural. Penelitian ini bertujuan untuk menghasilkan suatu model tematik-integratif berbasis sosiokultural yang layak bagi peserta didik dan mengetahui efektivitas perangkat pembelajaran tematik-integratif berbasis sosiokultural. Jenis penelitian ini adalah penelitian dan pengembangan. Pengembangan dilakukan dengan mengacu pada model pengembangan Borg and Gall yaitu ekplorasi, perencanaan, pengembangan produk, uji produk dan finalisasi. Subjek uji coba penelitian adalah seluruh peserta didik PAUD kabupaten Melawi. Hasil penelitian ini menunjukkan bahwa hasil validasi ahli, praktisi dan rekan sejawat menunjukkan perangkat pembelajaran tematik-integratif berbasis sosiokultural layak digunakan dengan kategori sangat baik. Keefektifan ditinjau dari hasil observasi dan angket memperoleh kategori sangat baik dan respon yang sangat positif.
\end{abstract}

Kata kunci: tematik integratif, perangkat pembelajaran, dan sosiokultural.

\section{Pendahuluan}

Berbagai upaya telah dilakukan oleh pemerintah demi mewujudkan cita-cita bangsa ini, yakni menjadi bangsa yang cerdas baik dari segi akademik, segi spiritual, maupun segi sosial. Hal ini selaras dengan apa yang telah diamanahkan dalam Undang-Undang Sistem Pendidikan Nasional Nomor 20 Tahun 2003 yang menjelaskan bahwa pendidikan nasional berfungsi me-ngembangkan kemampuan dan mem-bentuk watak serta peradaban bangsa yang beradab dalam rangka mencerdaskan kehidupan bangsa, bertujuan untuk berkembangnya potensi peserta didik agar menjadi manusia yang beriman dan bertakwa kepada Tuhan Yang Maha Esa, berakhlak mulia, sehat, berilmu, cakap, kreatif, serta menjadi warga negara yang demokratis dan bertanggung jawab. 
Menyikapi hal itu pemerintah selaku pemegang kekuasaan tertinggi, melakukan berbagai upaya dalam rangka mewujudkan tujuan pendidikan tersebut. Hal yang baru dan masih aktual adalah mengenai keputusan pemerintah untuk melakukan perubahan kurikulum, yaitu dari Kurikulum Tingkat Satuan Pendidikan (KTSP) ke Kurikulum 2013. Tidak bisa kita pungkiri bahwa pada saat ini pendidikan sudah menjadi hal yang sangat berpengaruh dalam segala aspek kehidupan manusia. Dalam rangka mengembangkan Kurikulum 2013, pemerintah telah melakukan persiapan dan melakukan uji publik sebelum Kurikulum 2013 tersebut benar-benar diterapkan di dalam dunia pendidikan di tanah air. Salah satu aspek yang akan mengalami perubahan diantaranya adalah model pembelajaran yang diterapkan di sekolahsekolah yaitu model tematik terintegrasi.

Pada dasarnya pembelajaran tematik dinyatakan dalam Depdiknas adalah pembelajaran terpadu yang menggunakan tema untuk mengaitkan beberapa mata pelajaran sehingga dapat memberikan pengalaman bermakna pada siswa. Pembelajaran tematik diharapkan mampu melahirkan siswa yang kreatif, cerdas, dan inovatif. Hal tersebut sejalan dengan tujuan perubahan kurikulum yang diungkapkan oleh pemerintah, yaitu "Dengan pembelajaran tematik-terintegratif di-harapkan siswa kita memiliki kompetensi sikap, keterampilan, dan pengetahuan yang jauh lebih baik. Mereka akan lebih kreatif, inovatif, dan lebih produktif, sehingga nantinya mereka bisa sukses dalam menghadapi berbagai persoalan dan tantangan di zamannya, memasuki masa depan yang lebih baik" (Sisdiknas: 2012).

Setidaknya rancangan pengembangan kurikulum yang dilakukan oleh pemerintah merupakan salah satu upaya dalam rangka mengatasi problematika yang tengah melanda bangsa ini. Salah satu diantaranya adalah nilainilai karakter bangsa yang mulai menurun. Termasuk di dalamnya nilai-nilai sosial budaya yang mulai terpinggirkan oleh nilai-nilai dan kebudayaan asing. Kondisi seperti ini juga dialami oleh sekolah Pendidikan Anak Usia Dini (PAUD) di Kabupaten Melawi. Oleh sebab itu, perlu dikembangkan model pembelajaran tematik-integratif yang berbasis sosiokultural pada PAUD di wilayah ini.

Di sisi lain telah ditegaskan pula bahwasanya proses pendidikan tidak boleh meninggalkan nilai-nilai sosial budaya sebagai kekayaan bangsa. Seperti yang tertuang dalam Peraturan Pemerintah No. 4 Pasal 4
Tahun 2011 tentang Tata Nilai Budaya yang menyebutkan bahwa tata nilai budaya yang harus dilestarikan meliputi: (1) tata nilai religius spiritual; (2) tata nilai moral; (3) tata nilai kemasyarakatan; (4) tata nilai adat dan tradisi; (5) tata nilai pendidikan dan pengetahuan; (6) tata nilai teknologi; (7) tata nilai penataan ruang dan arsitektur; (8) tata nilai mata pencaharian; (9) tata nilai kesenian; (10) tata nilai bahasa; (11) tata nilai benda cagar budaya dan kawasan cagar budaya; (12) tata nilai kepemimpinan dan pemerintahan, dan (13) tata nilai semangat.

Berdasarkan peraturan tersebut dapat diimplikasikan bahwa proses pendidikan di lingkungan formal khususnya tidak boleh dilepaskan dari nilai-nilai sosial budaya yang ada di lingkungan sekitar. Sehingga, nilai-nilai sosial budaya yang telah dilestarikan oleh para pendahulu kita tidak luntur hilang ditelan zaman. Maka dari itu pembelajaran yang efektif berbasis sosiokultural perlu dikembangkan oleh guru PAUD agar pembelajaran lebih bermakna bagi siswa.

Menurut Kyriacou (2009: 7), "effective teaching can be defined as teaching thatsuccessfully achieves the learning by pupils intended by the teacher". Pengajaran efektif dapat diartikan pengajaran yang didapatkan melalui keberhasilan pembelajaran siswa yang dilaksanakan oleh guru.

Model pembelajaran tersebut diharapkan dapat dikembangkan potensi manusia secara maksimal. Seperti halnya yang diungkapkan oleh Trianto (2011: 3), dimana pendidikan secara universal dapat dipahami sebagai penanaman nilai-nilai sosial budaya yang diyakini oleh sekelompok masyarakat agar dapat mem- pertahankan hidup dan kehidupan secara layak. Selain itu, guru juga diharapkan mampu menyampaikan pembelajaran secara efektif. Penyampaian pembelajaran yang seyogyanya terdapat dalam perencanaan pembelajaran berupa perangkat pembelajaran menjadi hal utama sebagai acuan pelaksanaan pembelajaran.

Pengembangan perangkat pembelajaran yang didesain berdasarkan pembelajaran tematik integratif dan berbasis sosiokultural menjadi salah satu solusi bahwa pembelajaran yang dilakukan secara formal tetap mengintegrasikan nilai-nilai sosial budaya.

\section{Tinjauan Pustaka}

Istilah pembelajaran terpadu sebagai konsep sering disamakan dengan integrated teaching and learning, integrated curriculum 
approach, a coherent curriculum approach. Pembelajaran tematik dimaknai sebagai pembelajaran yang dirancang dan dikemas berdasarkan tema-tema tertentu. Dalam pembahasannya tema-tema ditinjau dari berbagai mata pelajaran. Selanjutnya menurut Sukandi (2013: 109), menyatakan bahwa pembelajaran terpadu memiliki satu tema aktual, dekat dengan dunia siswa, dan ada kaitannya dengan kehidupan sehari-hari. Tema ini menjadi alat pemersatu materi yang beragam dari berbagai mata pelajaran.

Jadi, pada dasarnya pem-belajaran tematik-integratif merupakan pembelajaran yang menggabungkan beberapa bidang studi dalam satu tema dengan cara menetapkan prioritas kurikuler dan menemukan keterampilan, konsep, dan sikap yang saling tumpang tindih dalam beberapa bidang studi.

Perangkat pembelajaran me-rupakan salah satu hal penting yang perlu diperhatikan oleh guru sebagai pelaksana pembelajaran di sekolah. Perangkat pembelajaran yang baik akan sangat menunjang kegiatan pembelajaran di kelas sesuai dengan tujuan yang diharapkan. Guru perlu mendesain perangkat pembelajaran yang baik sehingga memungkinkan pembelajaran di kelas menjadi menyenangkan. Pembelajaran di kelas di desain dengan baik oleh guru sangat mendukung keberhasilan pembelajaran tersebut. Selanjutnya Suhadi (2007, p.3) mengungkapkan bahwa perangkat pembelajaran adalah sejumlah bahan, alat, media pembelajaran, petunjuk dan pedoman yang akan digunakan dalam kegiatan pembelajaran. Perangkat pembelajar-an yang dikembangkan dalam penelitian ini meliputi RPPM, RPPH, media pembelajaran dan tes hasil belajar.

Teori sosiokultural Vygotsky berfokus pada perkembangan kognisi anak dengan penekanan pada aktivitas yang bermakna sosial. Menurut Vygotsky, anak merupakan makhluk sosial yang menyusun pemikiran dan pemahaman terutama melalui interaksi sosial. Bodrova \& Leong (1996, p.8) menyatakan bahwa "Vygotsky believed that children construct their own understandings and do not passively reproduce what is represented to them". Kalimat tersebut memiliki makna yaitu Vygotsky percaya bahwa anak mengkonstruksi pemahaman dan tidak secara pasif mereproduksi apa yang disajikan kepadanya. Selain itu,

Vygotsky menekankan bahwa perkembangan kognitif dan pikiran anak tergantung pada perangkat yang disediakan oleh lingkungan dan konteks kultural di sekitarnya (Santrock, 2011, p.251). Perpaduan dari sisi sosial dan sisi kultural inilah kemudian dikenal dengan teori sosiokultural.

Selaras dengan uraian di atas, Feldman menyatakan sebagaimana dikutip berikut.

"Vygotky saw children as apprentices, learning cognitive strategies and other skills from adult and peer mentors who not only present new ways of doing things, but also provide assistance, instruction, and motivation. Consequently, he focused on the child's social and cultural world as the source of cognitive development" (Feldman, 2012, p.171).

Kalimat tersebut dapat dimaknai bahwa Vygotsky melihat anak sebagai pemagang. Dalam konteks ini, anak mempelajari strategi kognitif dan keterampilan dari orang dewasa dan mentor sebaya yang tidak hanya mengajarkan cara baru dalam mengerjakan sesuatu, tetapi juga menyediakan bantuan, pengajaran, dan motivasi. Dalam kenyataannya, memang tidak dapat dimungkiri bahwa kebanyakan yang dipelajari oleh anak berasal dari budaya di sekitarnya. Di samping itu, interaksi sosial dengan guru, orang tua, dan teman sebaya yang lebih berpengalaman mem-berikan kontribusi yang signifikan bagi perkembangan intelektual anak.

\section{Metodologi Penelitian}

Jenis penelitian yang digunakan dalam penelitian ini adalah penelitian dan pengembangan atau Research and Development (R\&D). Model pengembangan diadaptasi dari model pengembangan Borg and Gall dengan melakukan modifikasi menjadi lima prosedur pengembangan. Kelima prosedur tersebut adalah sebagai berikut: (1) eksplorasi, (2) perencana-an, (3) pengembangan draf, (4) uji produk, dan (5) finalisasi.

Uji coba yang dilakukan bertujuan untuk menyempurnakan perangkat pembelajaran yang dikem-bangkan dengan mempraktekkannya secara langsung di lapangan dan mengetahui keefektifan dari produk. Uji coba yang dilakukan meliputi tiga tahap, yaitu uji pendahuluan, uji utama dan uji coba terbatas. Uji pendahuluan dilakukan oleh ahli, praktisi dan rekan sejawat (expert judgment). Uji utama dilakukan pembelajaran pada satu sekolah. Uji coba terbatas dilakukan 
pembelajaran pada dua sekolah.

Subjek coba dalam penelitian dan pengembangan ini adalah sebagai berikut: uji pendahuluan subjeknya satu orang ahli materi atau ahli evaluasi yang berkompeten dalam pembelajaran tematik-integratif atau ahli perangkat pem-belajaran, tiga orang guru PAUD di Kabupaten Melawi dan satu orang rekan sejawat peneliti; uji utama subjeknya satu sekolah peserta didik kelompok B TK Global Jaya; dan uji coba terbatas subjeknya dua sekolah peserta didik kelompok B PAUD Muzakirin dan TK Dharma Wanita yang berjumlah 42 orang.

Teknik pengumpulan data yang digunakan dalam penelitian dan pengem- bagan ini antara lain wawancara, angket expert, observasi, dan angket guru. Wawancara dilakukan dengan tujuan untuk mengetahui pemahaman dan kesiapan guru menghadapi dan menerapkan pembelajaran tematik-integratif sesuai Kurikulum 2013, ketersediaan perangkat pembelajaran guru dan pengintegrasian sosiokultural dalam proses pembelajaran di beberapa PAUD. Teknik wawancara yang digunakan adalah wawancara tidak terstruktur atau terbuka (open ended). Angket expert bertujuan untuk menilai kelayakan produk yang dikembangkan. Penilaian produk ini dilakukan oleh ahli evaluasi atau ahli materi (perangkat pembelajaran), praktisi (guru PAUD) dan rekan sejawat peneliti. Tujuan dilakukan observasi adalah untuk mengetahui kesesuaian antara RPPM, RPPH media pembelajaran dan tes hasil belajar yang dikembangkan dengan kegiatan pembelajaran yang dilaksanakan oleh guru. Observasi dilakukan oleh dua orang observer. Angket guru diberikan dengan tujuan mengetahui respon guru yang telah melaksanakan pembelajaran menggunakan perangkat pembelajaran tematikintegratif berbasis sosio-kultural yang dikembangkan.

Instrumen pengumpulan data pada penelitian ini digunakan untuk mengumpulkan data pada tahap eksplorasi, tahap pengembangan produk, uji pendahuluan, uji utama dan uji coba terbatas. Instrumen yang digunakan dalam penelitian dan pengembangan ini adalah pedoman wawancara, lembar penilaian kelayakan perangkat pembelajaran, lembar observasi, lembar angket guru. Validasi perangkat pembelajaran melibatkan ahli evaluasi atau ahli materi, praktisi dan rekan sejawat peneliti. Lembar validasi yang digunakan adalah lembar penilaian Rencana Pelaksanaan Pembelajaran Mingguan (RPPM), lembar penilaian Rencana Pelaksanaan Pembelajaran Harian (RPPH), lembar penilaian media pembelajaran, dan lembar penilaian tes hasil belajar.

Data yang diperoleh melalui pedoman wawancara, lembar penilaian produk, lembar observasi, dan lembar angket dianalisis secara statistik kualitatif dan kuantitatif. Data kualitatif dalam penelitian dan pengembangan ini diperoleh dari: (1) hasil wawancara pada tahap eksplorasi; (2) komentar dan saran yang diperoleh dari ahli materi atau ahli evaluasi, praktisi, dan rekan sejawat; dan (3) hasil observasi. Data yang diperoleh dianalisis dan dideskripsikan secara kualitatif untuk merevisi produk yang dikembangkan.

Data kuantitatif dalam penelitian dan pengembangan berupa: (1) skor penilaian oleh ahli materi, ahli evaluasi, praktisi/guru kelas IV SD dan rekan sejawat peneliti; (2) skor hasil observasi (kegiatan guru dan kegiatan peserta didik); dan (3) skor angket guru. Data kuantitatif dianalisis dengan teknik sebagai berikut: (a) tabulasi semua data yang diperoleh, (b) menghitung skor total dan rerata skor dari setiap komponen, (c) mengubah rerata skor menjadi nilai dengan kriteria.

Menurut Azwar (2013, p.163) skor yang diperoleh kemudian dikonversikan menjadi kriteria. Dalam penelitian ini ditetapkan nilai kelayakan produk minimal "B" kategori "Baik". Dengan demikian, hasil penilaian ahli materi/ahli perangkat pembelajaran tematikintegratif, ahli evaluasi, praktisi dan rekan sejawat jika memberi hasil akhir " $B$ " atau "Baik", maka produk pengembangan layak digunakan sebagai perangkat pembelajaran tematik -integratif bebasis sosiokultural. Namun, jika hasil analisis data yang tidak memenuhi kategori "Baik" pada penelitian ini akan dijadikan bahan pertimbangan untuk merevisi perangkat pembelajaran sebelum diujicobakan.

Sedangkan kriteria keefektifan perangkat- pembelajaran yang diperoleh dari hasil angket peserta didik dikatakan tercapai apabila paling sedikit $70 \%$ peserta didik subjek uji mencapai kategori "Baik". Sedangkan kriteriakeefektifanperangkat pembelajaran yang diperoleh dari hasil angket guru dikatakan tercapai apabila paling sedikit $70 \%$ respon guru mencapai kategori "Mudah dilaksanakan".

Penentuan keefektifan perangkat pembelajaran tematik-integratif berbasis sosiokultural hasil pengembangan dilihat dari 
pencapaian aspek keefektifan yang ditetapkan berdasarkan analisis data uji coba terbatas yang terdiri dari dua aspek penilaian, yaitu hasil observasi pembelajaran dan angket.

Pengembangan $\mathrm{p}$ e $\mathrm{r}$ a $\mathrm{n} \mathrm{g} \mathrm{k}$ a $\mathrm{t} \mathrm{p}$ e $\mathrm{m}$ belajaran tematik-integratif berbasis sosiokultural ini dilakukan dengan metode research and development (R\&D) . Model pengembangan diadaptasi dari model pengembangan Borg and Gall dengan melakukan modifikasi. Prosedur yang diadaptasi tersebut meliputi lima tahap yaitu

(1) tahap eksplorasi, (2) tahap peren-canaan,

(3) tahap pengembangan produk, (4) tahap uji produk dan (5) tahap finalisasi. Tahap eksplorasi dilakukan dengan dua kegiatan utama yaitu penelitian awal dan mengumpulkan informasi. Tahap perencanaan dilakukan kegiatan pengembangan instrumen. Tahap pengembangan produk dilakukan dengan pengembangan produk awal.

Tahap uji produk terdiri dari uji pendahuluan, revisi hasil uji pendahuluan, uji utama, revisi hasil uji utama, uji coba terbatas, dan revisi hasil uji coba terbatas. Tahap finalisasi berupa perbaikan dan validasi akhir produk sehingga dihasilkan produk akhir.

Data hasil uji coba produk terdiri dari hasil uji pendahuluan, hasil uji utama, dan hasil uji coba terbatas. Data yang diperoleh dalam uji pendahuluan merupakan data hasil penilaian kelayakan produk yang dilakukan oleh ahli, praktisi dan rekan sejawat. Berdasarkan hasil penilaian dari ahli, praktisi, dan rekan sejawat dapat diketahui kelayakan perangkat pembelajaran (produk) yang dikembangkan. Data hasil penilaian perangkat pembelajaran yang berupa rerata skor dikonversikan menjadi nilai skala lima. Konversi hasil penilaian perangkat pembelajaran yang diuraikan terbagi menjadi tiga hal yaitu, konversi interval rerata skor tiap aspek yang ada pada perangkat pembelajaran, rerata skor tiap validator dari keseluruhan aspek dan keseluruhan validator.

Data hasil penilaian kelayakan dari RPPM pembelajaran yang dikembangkan sebagai berikut; (a) hasil penilaian RPPM dari ahli berdasarkan keseluruhan indikator diperoleh rerata skor sebesar 4,45 dengan nilai A berkategori "Sangat Baik"; (b) hasil penilaian RPPM dari ketiga praktisi berdasarkan keseluruhan indikator diperoleh rerata skor sebesar 4,47 dengan nilai A berkategori "Sangat Baik"; (c) hasil penilaian RPPM dari rekan sejawat berdasarkan keseluruhan indikator diperoleh rerata skor sebesar 4,33 dengan nilai A berkategori "Sangat Baik".

Dari hasil penilaian kelayakan RPPM secara umum yang meliputi hasil penilaian dari ahli, praktisi dan rekan sejawat memperoleh rerata skor secara keseluruhan sebesar 4,42 dengan nilai A. Dengan demikian dapat dinyatakan bahwa menurut ahli, praktisi dan rekan sejawat, RPPM untuk pembelajaran tematik-integratif yang dikembangkan dinyatakan layak untuk digunakan pada uji coba dengan kategori "Sangat Baik". Diagram hasil penilaian RPPM dari keseluruhan indikator pada masing-masing ahli, praktisi, dan rekan sejawat disajikan dalam Gambar 1 berikut.

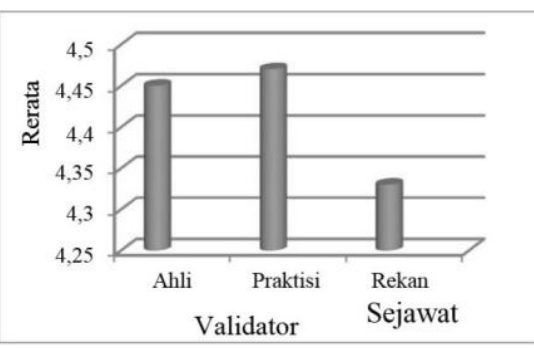

\section{Gambar 1. Diagram Penilaian RPPM dari Masing-masing Ahli, Praktisi, dan Rekan Sejawat}

Data hasil penilaian RPPH oleh masingmasing kelompok validator diuraikan sebagai berikut; (a) hasil penilaian RPPH dari ahli berdasarkan keseluruhan indikator diperoleh rerata skor sebesar 4,41 dengan nilai A berkategori "Sangat Baik"; (b) hasil penilaian RPPH dari ketiga praktisi berdasarkan keseluruhan indikator diperoleh rerata skor sebesar 4,49 dengan nilai A berkategori "Sangat Baik"; dan (c) hasil penilaian RPPH dari rekan sejawat berdasarkan keseluruhan indikator diperoleh rerata skor sebesar 4,37 dengan nilai A berkategori "Sangat Baik".

Dari hasil penilaian kelayakan RPPH yang meliputi hasil penilaian dari ahli, praktisi dan rekan sejawat memperoleh rerata skor secara keseluruhan sebesar 4,42 dengan nilai A. Dengan demikian dapat dinyatakan bahwa menurut ahli, praktisi dan rekan sejawat, RPP untuk pembelajaran tematik-integratif yang dikembangkan dinyatakan layak untuk digunakan pada uji coba dengan kategori "Sangat Baik". Diagram hasil penilaian RPP dari keseluruhan indikator pada masingmasing ahli, praktisi, dan rekan sejawat disajikan dalam Gambar 2 berikut. 


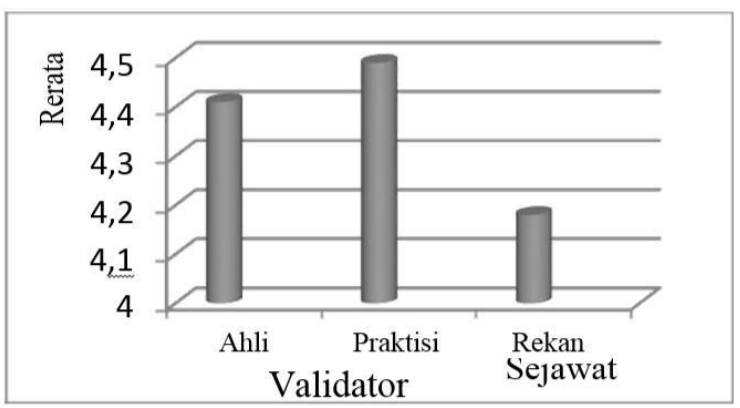

Gambar 2. Diagram Penilaian RPPH dari Masing-masing Ahli, Praktisi dan Rekan Sejawat

Data hasil penilaian media pembelajaran oleh masing-masing kelompok validator diuraikan sebagai berikut; (a) hasil penilaian media pembelajaran dari ahli berdasarkan keseluruhan indikator diperoleh rerata skor sebesar 4,78 dengan nilai A berkategori "Sangat Baik"; (b) hasil penilaian media pembelajaran dari ketiga praktisi berdasarkan keseluruhan indikator diperoleh rerata skor sebesar 4,51 dengan nilai A berkategori "Sangat Baik"; dan (c) hasil penilaian media pembelajaran dari rekan sejawat berdasarkan keseluruhan indikator diperoleh rerata skor sebesar 4,47 dengan nilai A berkategori "Sangat Baik".

Dari hasil penilaian kelayakan media pembelajaran yang meliputi hasil penilaian dari ahli, praktisi dan rekan sejawat memperoleh rerata skor secara keseluruhan sebesar 4,59 dengan nilai A. Dengan demikian dapat dinyatakan bahwa menurut ahli, praktisi dan rekan sejawat, media pembelajaran untuk pembelajaran tematik-integratif yang dikembangkan dinyatakan layak untuk digunakan pada uji coba dengan kategori "Sangat Baik". Diagram hasil penilaian media pembelajaran dari keseluruhan indikator pada masingmasing ahli, praktisi, dan rekan sejawat disajikan dalam Gambar 3 berikut.

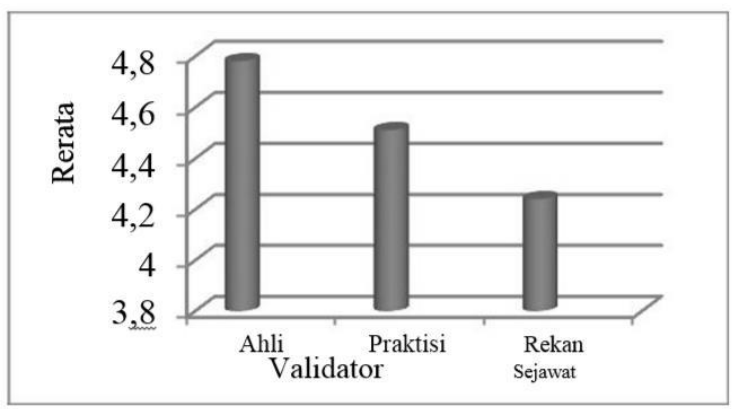

Gambar 3. Diagram Penilaian Media Pembelajaran Dari Masing-masing Ahli, Praktisi dan Rekan Sejawat
Data hasil penilaian tes hasil belajar oleh masing-masing kelompok validator diuraikan sebagai berikut; (a) hasil penilaian tes hasil belajar dari ahli berdasarkan keseluruhan indikator diperoleh rerata skor sebesar 4,65 dengan nilai A berkategori "Sangat Baik"; (b) hasil penilaian tes hasil belajar dari ketiga praktisi berdasarkan keseluruhan indikator diperoleh rerata skor sebesar 4,36 dengan nilai $A$ dan kategori "Sangat Baik"; dan hasil penilaian tes hasil belajar dari rekan sejawat berdasarkan keseluruhan indikator diperoleh rerata skor sebesar 4,73 dengan nilai A berkategori "Sangat Baik".

Dari hasil penilaian kelayakan tes hasil belajar yang meliputi hasil penilaian dari ahli, praktisi dan rekan sejawat memperoleh rerata skor secara keseluruhan sebesar 4,58 dengan nilai A. Dengan demikian dapat dinyatakan bahwa menurut ahli, praktisi dan rekan sejawat, tes hasil belajar untuk pembelajaran tematik-integratif yang dikembangkan dinyata-kan layak untuk digunakan pada uji coba dengan kategori "Sangat Baik". Diagram hasil penilaian tes hasil belajar dari keseluruhan indikator pada masing-masing ahli, praktisi, dan rekan sejawat disajikan dalam Gambar 4 berikut.

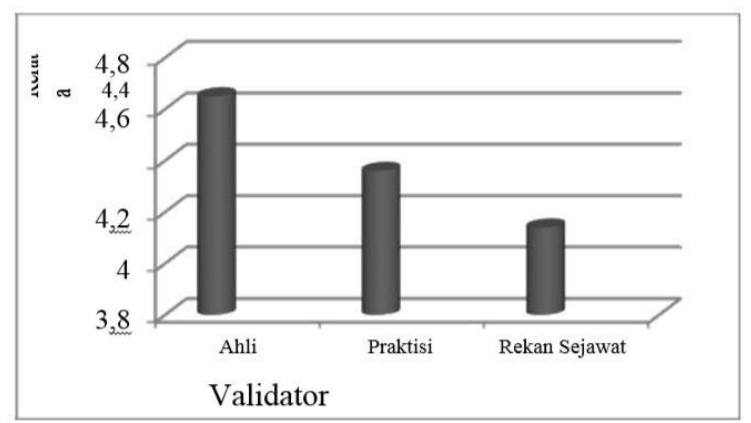

\section{Gambar 4. Diagram Penilaian Tes Hasil Belajar dari Masing-masing Ahli, Praktisi dan Rekan Sejawat}

Secara umum kualitas perangkat pembelajaran yang meliputi RPPM, RPPH, media pembelajaran dan tes hasil belajar yang dinilai oleh ahli, praktisi dan rekan sejawat pada uji pendahuluan diperlihatkan pada Gambar 5 berikut. 


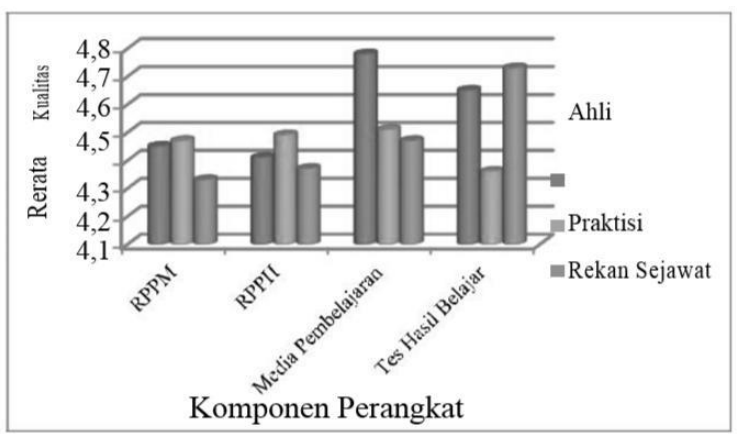

Gambar 5. Diagram Penilaian Kualitas Perangkat Pembelajaran Oleh Ahli, Praktisi dan Rekan Sejawat

Informasi yang diperoleh dalam uji utama terkumpul dalam data keterlaksanaan pembelajaran melalui lembar observasi dan data angket. Keterlaksanaan pembelajaran tematik-integratif berbasis sosiokultural secara sistematis tertuang dalam lembar observasi kegiatan guru dan peserta didik. Data hasil observasi kegiatan guru pada keseluruhan pembelajaran diperoleh rerata skor sebesar 8,00 dengan nilai B berkategori "Baik". Dengan demikian dapat dinyatakan bahwa proses pembelajaran menggunakan perangkat pembelajar-an yang dikembangkan pada uji utama dilaksanakan guru dengan baik. Keterlaksanaan pembelajaran tematikintegratif berbasis sosiokul-tural dilihat dari hasil observasi kegiatan guru untuk setiap pembelajaran dapat dilihat secara lebih jelas pada Gambar 6 berikut.

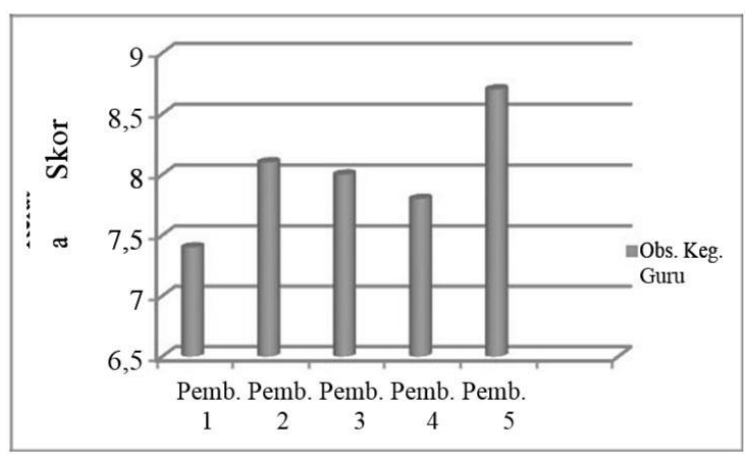

\section{Gambar 6. Diagram Hasil Observasi Kegiatan Guru untuk Tiap Pembelajaran pada Uji Utama}

Dari diagram di atas dapat disimpulkan bahwa keseluruhan pembelajaran berdasarkan keseluruh-an indikator observasi kegiatan guru dalam melaksanakan pembelajaran telah memenuhi kategori yang ditetapkan yaitu minimal "Baik", maka keterlaksanaan pembelajaran yang telah dilakukan efektif.
Sedangkan rerata skor observasi kegiatan peserta didik secara keseluruhan kegiatan pembelajaran diperoleh sebesar 7,34 dengan nilai B berkategori "Baik". Dengan demikian dapat dinyatakan bahwa proses pembelajaran menggunakan perangkat pembelajar-an yang dikembangkan pada uji utama dilaksanakan secara efektif. Keterlaksanaan pembelajaran tematikintegratif berbasis sosiokultural dilihat dari hasil observasi kegiatan peserta didik untuk setiap pembelajaran dapat dilihat secara lebih jelas pada Gambar 7 berikut.

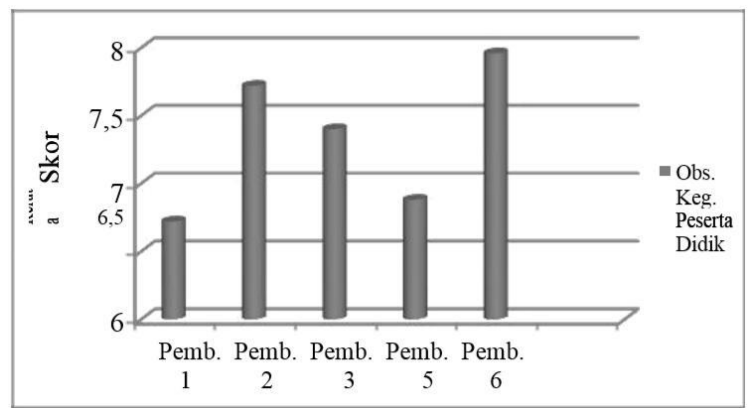

\section{Gambar 7. Diagram Hasil Observasi Kegiatan Peserta Didik untuk Tiap Pembelajaran pada Uji Utama}

Data hasil angket guru dari keseluruhan indikator diperoleh rerata skor sebesar 3,96 dengan nilai B berkategori "Mudah dilaksanakan". Dengan demikian dapat dinyatakan bahwa proses pembelajaran menggunakan perangkat pembelajar-an yang dikembangkan pada uji utama, menurut guru mudah dilaksanakan.

Perangkat pembelajaran tematikintegratif berbasis sosiokul-tural hasil revisi berdasarkan masukan validator pada uji pendahuluan dan telah digunakan pada uji utama, selanjutnya diujicobakan pada 42 orang peserta didik kelompok B PAUD Muzakirin dan TK Dharma Wanita melalui uji coba terbatas. Untuk mengetahui apakah perangkat yang dikembangkan dapat diterapkan dalam proses pembelajaran secara efektif maka pelaksanaan uji coba terbatas menggunakan dua sekolah. Kedua sekolah ini merupakan sekolah yang memiliki kemampuan awal peserta didik yang sama (homogen).

Informasi yang diperoleh dalam uji coba terbatas terkumpul dalam data keterlaksanaan pembelajaran melalui lembar observasi, masukan oleh praktisi dan data angket. Berdasarkan hasil observasi kegiatan guru dapat dikatakan bahwa setiap indikator pengamatan kegiatan pembelajaran yang 
dilakukan guru sudah memenuhi kategori yang ditetapkan yaitu minimal "Baik". Maka perangkat pembelajaran tematik-integratif berbasis sosiokultural yang digunakan guru dalam proses pembelajaran pada kelas eksperimen sudah memenuhi kriteria efektif.

Hasil observasi kegiatan guru dalam keseluruhan pembelajaran diperoleh rerata skor sebesar 4,66 dengan nilai A berkategori "Sangat Baik". Dengan demikian dapat dinyatakan bahwa proses pembelajaran menggunakan perangkat pembelajaran berbasis sosiokultural sudah efektif. Keterlaksanaan pembelajaran tematikintegratif dilihat dari hasil observasi kegiatan guru untuk setiap pembelajaran dapat dilihat secara lebih jelas pada Gambar 8 berikut.

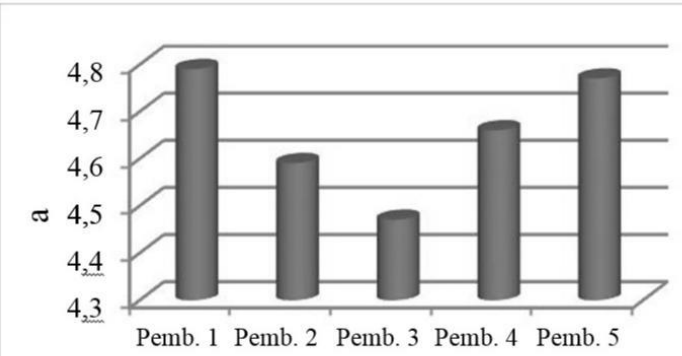

\section{Gambar 8. \\ Diagram Observasi Kegiatan Guru untuk Tiap Pembelajaran pada Uji Coba Terbatas}

Hasil observasi kegiatan peserta didik secara keseluruhan kegiatan pembelajaran diperoleh sebesar 4,49 dengan nilai A berkategori "Sangat Baik". Dengan demikian dapat dinyatakan bahwa proses pembelajaran menggunakan perangkat pembelajaran tematik-integratif berbasis sosiokultural sudah efektif. Keterlaksanaan pembelajaran tematikintegratif dilihat dari hasil observasi kegiatan peserta didik untuk setiap pembelajaran dapat dilihat secara jelas pada Gambar 9 berikut.

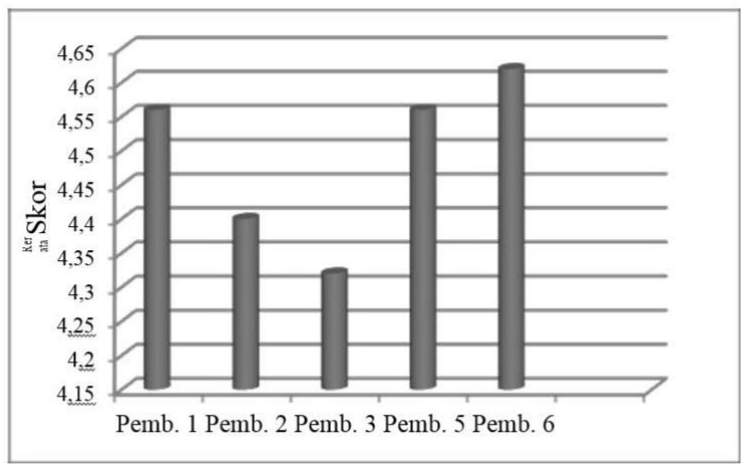

Gambar 9. Diagram Hasil Observasi

Kegiatan Peserta Didik untuk Tiap Pembelajaran pada Uji Coba Terbatas
Rerata skor angket guru dari keseluruhan indikator diperoleh sebesar 13,84 dengan nilai A berkategori "Sangat mudah dilaksanakan". Dengan demikian dapat dinyatakan bahwa proses

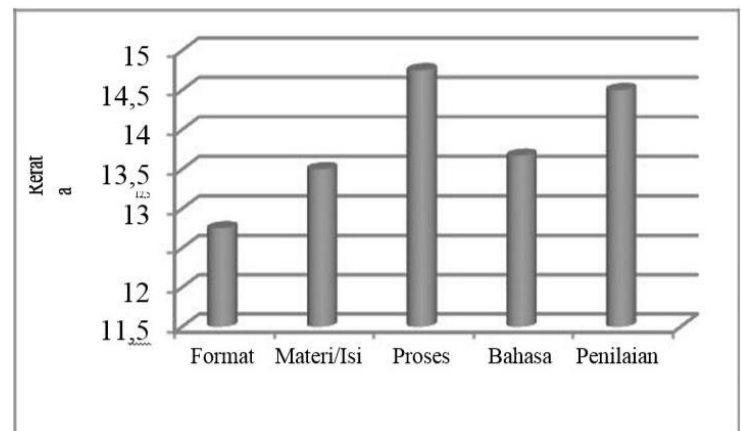

\section{Gambar 10. Diagram Hasil Angket Guru dari Tiap Indikator pada Uji Coba Terbatas}

Dari hasil penilaian keempat komponen perangkat pembelajaran tersebut, setiap aspek penilaian memenuhi kriteria minimal "Baik". Sesuai dengan kualitas produk yang telah ditetapkan bahwa produk yang dikembangkan dianggap layak jika aspek-aspek yang dinilai pada perangkat pembelajaran mencapai kategori minimal "Baik". Dengan demikian perangkat pembelajaran tematik-integratif berbasis sosiokul-tural yang dikembangkan dinilai layak digunakan pada uji utama dan uji coba terbatas.

Kemaksimalan hasil belajar yang diperoleh dan respon positif serta proses pembelajaran yang menyenangkan bagi peserta didik dikarenakan beberapa hal, antara lain: (1) perangkat pembelajaran yang digunakan peserta didik berbeda dari perangkat pembelajaran sebelumnya; (2) proses belajar mengajar secara kontekstual, tidak hanya berpaku berada di dalam kelas namun berada di lingkungan peserta didik;

(3) kegiatan pembelajaran melibatkan peserta didik secara aktif; (4) sumber belajar dan media pembelajaran yang digunakan sangat dekat dengan kehidupan peserta didik; dan (5) peserta didik melakukan proses belajar tidak hanya dengan guru, tetapi dengan teman sebaya, orang tua, orang dewasa, lingkungan dan budaya. Perangkat pembelajaran yang digunakan dikatakan berbeda karena perangkat tersebut berbasis sosiokultural. Proses belajar mengajar tidak hanya monoton di dalam kelas namun di luar kelas dan di lingkungan masyarakat peserta didik. 
Hal tersebut sejalan dengan teori Vygotsky yang menekankan pada hakikat sosiokultural dari pembelajaran. Dua implikasi utama dari tori Vygotsky dalam pembelajaran. Pertama, dikehendaki-nya susunan kelas berbentuk pembelajaran kooperatif antar peserta didik, sehingga peserta didik dapat berinteraksi disekitar tugas-tugas yang sulit dan saling memunculkan strategi pemecahan masalah yang efektif di dalam masing-masing zone of proximal development mereka. Pembelajaran kooperatif ini terwujud melalui kegiatan pembelajaran secara berkelompok yang telah dilaksanakan yang terdiri dari 5 sampai 6 peserta didik. Kedua, pendekatan Vygotsky dalam pengajaran menekankan scaffolding sehingga peserta didik semakin lama semakin bertanggungg jawab terhadap pembelajarannya sendiri. Vygotsky meyakini bahwa orang-orang dan lingkungan budaya mereka berperan dalam sistem interaksi sosial. Melalui komunikasi dan tindakan, orangorang yang berada dalam lingkungan anak mengajar-kan alat -alat kepada anak (misalnya, bahasa simbol, tanda) yang mereka butuhkan untuk memperoleh kompetensi (Schunk, 2012, p.581). Interaksi sosial dengan guru, orang tua dan teman sebaya yang lebih berpengalaman memberikan kontribusi yang signifikan bagi perkembangan intelektual anak. Hal ini dipertegas oleh Jackman (2012, p.10) sebagaimana dikutip berikut. "Much of what a child learns comes from the culture around him. In addition, interactions with teachers, parents, and more experienced peers contribute significantly to a child's intellectual development."

Me nurut Vygotskyanak-a n a $\mathrm{k}$ mengontruksi pengetahuan melalui interaksi sosial. Sebagaimana dikemukakan oleh Warsono dan Hariyanto (2013, p.59) bahwa asumsi pokok teori Vygotsky adalah "What the child can do in cooperation today he can do alone tomorrow." Pernyataan ini mengisyaratkan bahwa apa yang dapat dilakukan oleh pada peserta didik dengan bekerja sama pada hari ini dapat dilakukannya sendiri pada masa mendatang. Dari semua aspek tersebut didukung melalui perangkat pembelajaran tematik-integratif berbasis sosiokultural yang dikembangkan dalam penelitian ini. Selain proses pembelajaran yang berlandaskan konstruktivisme, pada pembelajaran tematik-integratif juga dilakukan penilaian otentik. Bentuk penilaian otentik akan mengharuskan peserta didik membuat tulisan berupa penyampaian pikiran, mendiskusikan apa yang telah mereka pelajari dan mengapa pengetahuan ini berguna di dunia atau mendemonstrasikan dan mengaplikasikan keterampilan yang telah diperoleh.

Berdasarkan kesesuaian antara teori dan aplikasi yang terjadi dilapangan selama proses penelitian inilah menjadi dasar bahwa perkembangan kognitif peserta didik mengalami peningkatan. Selain beberapa hal yang diuraikan di atas, keberhasilan atau ketuntasan dan peningkatan hasil belajar peserta didik yang tercapai juga menunjukkan bahwa proses pembelajaran menggunakan pendekatan saintifik (saintific approach), sebagaimana yang dirancang oleh peneliti memiliki pengaruh yang sangat signfikan. Hal tersebut dapat juga dilihat dari hasil penilaian autentik yang diperoleh peserta didik sangat baik, baik penilaian kinerja, penilaian proyek, penilaian portofolio maupun penilaian tertulisnya. Dari hal-hal tersebut maka dapat ditarik kesimpulan bahwa pembelajaran menggunakan perang-kat pembelajaran tematik-integratif berbasis sosiokultural ini dapat meningkatkan hasil belajar peserta didik. Peserta didik mampu menerapkan pengetahuan, keteram-pilan, dan tingkah laku dalam menyelesaikan masalah sehari-hari, serta peserta didik juga lebih peka untuk mengamati fenomena-fenomena yang ada dilingkungan sekitar.

\section{Kesimpulan}

Berdasarkan hasil penelitian dan pengembangan perangkat pembelajaran tematik-integratif pada tema Kebutuhanku berbasis sosiokultural dikatakan layak untuk setiap komponen perangkat adalah sebagai berikut; (a) Rencana Pelaksanaan Pembelajaran Mingguan (RPPM) tematikintegratif berbasis sosiokultural dikembangkan dengan mengintegrasikan nilai-nilai budaya pada kegiatan pembelajaran, menggunakan penilaian otentik, dan menggunakan sumber belajar yang ada disekitar peserta didik dan relevan dengan kebudayaan di lingkungan peserta didik; (b) Rencana Pelaksanaan Pembelajaran Harian (RPPH) tematikintegratif berbasis sosiokultural dikembangkan dengan menggunakan pendekatan saintifik pada langkah-langkah pembelajaran, mengintegrasikan nilai-nilai budaya pada kegiatan pembelajaran, menumbuhkan interaksi sosial pada pelaksanaan pembelajaran, menggunakan penilaian otentik, menggunakan sumber belajar yang ada disekitar peserta didik dan relevan dengan kebudayaan di lingkungan 
peserta didik; (c) Media pembelajaran tematik-integratif berbasis sosiokul-tural dikembangkan menggunakan benda-benda yang ada disekitar peserta didik dan mengandung nilai budaya, permainan tradisional yang relevan dengan materi, lagu daerah, sumber alam lingkungan sekitar dan menggunakan media yang mencakup kegiatan saintifik pada proses pembelajaran;

(d) Tes hasil belajar tematik-integratif berbasis sosiokul-tural dikembangkan melalui bentuk-bentuk lembar kerja peserta didik yang mencakup pertanyaan yang berkaitan dengan budaya peserta didik dan relevan dengan materi pelajaran.

Keefektifan perangkat pem-belajaran tematik-integratif berbasis sosiokultural berdasarkan hasil observasi kegiatan guru, observasi kegiatan peserta didik serta angket dinyatakan efektif.

\section{Daftar Pustaka}

Azwar, S. (2013). Tes prestasi fungsi dan pengembangan pengukuran prestasi belajar. Edisi 2, Yogyakarta: Pustaka Pelajar.

Bodrova, E \& Leong, D.J. (1996). Tools of The Mind. The Vygotskian Approach to Early Childhood Education, Englewood Cliffs: Prentice-Hall. Inc.

Feldman, R.S. (2012). Discovering the Life Span,Second Edition, New York: Pearson Prentice Hall.

Jackman, L.H. (2012). Early Education Curriculum, Bemidji: Wadasworth.
Mulyasa, E. (2013). Pengembangan dan Implementasi Kurikulum 2013. Perubahan dan Pengembangan Kurikulum 2013 Merupakan Persoalan Penting dan Genting, Bandung: Remaja Rosdakarya.

Santrock, J.W. (2011). Masa perkembangan anak (Terjemahan). (Edisi 11). New York: McGraw Hill. (Buku asli diterbitkan tahun 2009)

Sisdiknas. (2012). Uji publik kurikulum 2013: penyederhanaan, tematikintegratif.(http://www.kemdiknas. go.id/ kemdikbud/uji-publik-kurikulum2013-1). Diakses pada tanggal 10/07/2016 pukul 09.00 WIB.

Schunk, D.H. (2012). Learning Theories an Educational

Perspective, Boston: Person.

Suhadi. 2007. Penyusunan Perangkat Pembelajaran dalam Kegiatan

Lesson Study. (http://suhadinet.wordpress. com/ 2008/05/28/penyusunanperangkat-perangkat-pembelajarandalam-kegiatan-lesson-study/). Diakses pada tanggal 24 Juli 2017

Sukandi, U. (2003). Belajar Aktif dan Terpadu, Surabaya: Duta Graha Pustaka.

Tilaar, H.A.R \& Nugroho, R. (2009). Kebijakan Pendidikan, Yogyakarta: Pustaka Pelajar.

Warsono \& Hariyanto. (2013). Pembelajaran Aktif, Teori dan Asesmen, Bandung: Remaja Rosdakarya. 